\title{
The acute effect of commercially available pulse powders on postprandial glycaemic response in healthy young men
}

\author{
G. Harvey Anderson ${ }^{1 *}$, Yudan Liu ${ }^{1}$, Christopher E. Smith ${ }^{1}$, Ting Ting Liu ${ }^{1}$, Maria Fernanda Nunez ${ }^{1}$, \\ Rebecca C. Mollard ${ }^{1}$ and Bohdan L. Luhovyy ${ }^{2}$ \\ ${ }^{1}$ Department of Nutritional Sciences, Faculty of Medicine, University of Toronto, 150 College Street, Toronto, ON, \\ Canada M5S $3 E 2$ \\ ${ }^{2}$ Department of Applied Human Nutrition, Mount Saint Vincent University, Halifax, Nova Scotia, Canada B3M 2J6
}

(Submitted 29 January 2014 - Final revision received 24 July 2014 - Accepted 22 August 2014 - First published online 20 October 2014)

\begin{abstract}
Whole pulses (beans, peas, chickpeas and lentils) elicit low postprandial blood glucose (BG) responses in adults; however, their consumption in North America is low. One potential strategy to increase the dietary intake of pulses is the utilisation of commercial pulse powders in food products; however, it is unclear whether they retain the biological benefits observed with whole pulses. Therefore, the present study examined the effects of commercially prepared pulse powders on BG response before and after a subsequent meal in healthy young men. Overall, three randomised, within-subject experiments were conducted. In each experiment, participants received whole, puréed and powdered pulses (navy beans in Expt 1; lentils in Expt 2; chickpeas in Expt 3) and whole-wheat flour as the control. All treatments were controlled for available carbohydrate content. A fixed-energy pizza meal $(50 \cdot 2 \mathrm{~kJ} / \mathrm{kg}$ body weight $)$ was provided at $120 \mathrm{~min}$. BG concentration was measured before (0-120 min) and after (140-200 min) the pizza meal. BG concentration peaked at $30 \mathrm{~min}$ in all experiments, and pulse forms did not predict their effect on BG response. Compared with the whole-wheat flour control, navy bean treatments lowered peak BG concentrations (Expt $1, P<0.05$ ), but not the mean BG concentration over 120 min. The mean BG concentration was lower for all lentil (Expt 2, $P=0 \cdot 008$ ) and chickpea (Expt 3, $P=0 \cdot 002$ ) treatments over 120 min. Processing pulses to powdered form does not eliminate the benefits of whole pulses on BG response, lending support to the use of pulse powders as value-added food ingredients to moderate postprandial glycaemic response.
\end{abstract}

Key words: Navy bean powder: Lentil powder: Chickpea powder: Blood glucose

Obesity continues to increase worldwide ${ }^{(1)}$ and poses a well-known risk for metabolic derangements such as insulin resistance and type 2 diabetes $^{(2)}$. A potential dietary approach to curb weight gain and help regulate glycaemic control is to identify and encourage the consumption of satiating and lowenergy-dense foods. Frequent consumption of whole pulses, the edible seeds of legumes or pod-bearing plants, including beans, chickpeas, yellow peas and lentils ${ }^{(3)}$, is associated with a higher-quality diet ${ }^{(4,5)}$, lower body weight ${ }^{(6)}$ and improved markers of long-term glycaemic control ${ }^{(7)}$. Acutely, whole pulses lower postprandial glycaemic response ${ }^{(8-13)}$, reduce hunger ${ }^{(12,14-17)}$ and suppress food intake ${ }^{(12,13)}$ up to 2 to $6 \mathrm{~h}$ following their intake. Of these benefits, reduced blood glucose (BG) excursions are of particular importance ${ }^{(18)}$ as postprandial hyperglycaemia is an early abnormality of glycaemic control associated with type 2 diabetes ${ }^{(19)}$. Despite their high nutrient profile and associated health benefits, pulse consumption remains notably low, especially in pulse-producing regions such as North America ${ }^{(5)}$.

To increase pulse consumption, industrially processed pre-cooked ground pulses (pulse powders) are being developed for incorporation of pulses into a diverse range of foods ${ }^{(20)}$. These powders require minimal cooking time and can be easily added to pastas, breads, cookies, energy bars and soups ${ }^{(21)}$. While processing generally affects the starch in pulses and can alter their biological effects ${ }^{(22-25)}$, the impact of industrial processing on the biological functionality of pulses has received little attention.

To date, studies that have prepared pulse powders by cooking, drying and grinding in a laboratory setting point to a higher glycaemic response from pulse powders compared with whole pulses ${ }^{(23,24)}$. However, these earlier results may not reflect the effects of industrial methods typically employed to process whole pulses to powder form ${ }^{(26,27)}$. Therefore, the

Abbreviation: BG, blood glucose.

* Corresponding author: Dr G. H. Anderson, fax +1 416978 5882, email harvey.anderson@utoronto.ca 
objective of the present study was to compare the acute effects of commercially prepared pulse powders and whole pulses on glycaemic response in healthy young men.

\section{Methods}

\section{Subjects}

Healthy males aged 18-30 years old with a normal BMI $\left(20-24.9 \mathrm{~kg} / \mathrm{m}^{2}\right)^{(28)}$ were recruited via advertisements around the University of Toronto Saint George Campus, in local newspapers and on student websites. To reduce between-subject variation and the effects of potential confounders, subjects were excluded if they had diabetes mellitus or any other metabolic disorders; were taking medications; were dieting; were frequent breakfast skippers, were smokers; or participated in any other nutrition-related studies within 4 weeks before the present study. Previous short-term studies have shown that a minimum of eight to ten participants are needed to assess the differences in glycaemic response ${ }^{(29,30)}$. In addition, sample size analysis using data from a fixed-meal whole-pulse study following a similar within-subject design determined that ten subjects are required to detect a difference of $1.0 \mathrm{mmol} / \mathrm{l}$ in $\mathrm{BG}$ concentration at $30 \mathrm{~min}$ (peak) between treatments at a power level of $0.8(\alpha=0.05)^{(31)}$. Additional subjects were recruited to account for dropouts. Overall, seventeen subjects were recruited and completed Expt 1, and twelve subjects were recruited and completed Expt 2 and 3; no participants terminated the study. The present study was conducted according to the guidelines laid down in the Declaration of Helsinki, and all procedures involving human subjects were approved by the University of Toronto Health Sciences Research Ethics Board. Written informed consent was obtained from all subjects.

\section{Study design}

The experiments conducted in the present study followed a within-subject, randomised, repeated-measure design. Healthy young men attended four sessions on a weekly basis during which they received three treatments (whole canned pulses, puréed canned pulses and pulse powders) or wholewheat flour as a control in random order. Each experiment investigated commercially available whole and powdered forms of commonly consumed pulse types prepared with tomato sauce.

The treatments and control used in the present study were as follows: whole canned navy beans $\left(188.0 \mathrm{~g}\right.$; FERMA ${ }^{\circledR}$ Import \& Export Limited; $70.0 \mathrm{ml}$ filtered water), puréed canned navy beans (188.0 g; FERMA ${ }^{\circledR}$ Import \& Export Limited, $70.0 \mathrm{ml}$ filtered water), whole navy bean powder (62.5 g, VegaFull ${ }^{\circledR}$ Instant Dehydrated Whole Navy Bean Powder; manufactured and donated by $\mathrm{ADM}^{\circledR}$ Edible Bean Specialties, Inc.; $195.5 \mathrm{ml}$ filtered water; $0.90 \mathrm{~g} \mathrm{NaCl}$ ), or allpurpose whole-wheat flour $\left(39.5 \mathrm{~g}\right.$, Robin $\operatorname{Hood}^{\circledR}$, Smucker Foods of Canada Company; $208.0 \mathrm{ml}$ filtered water; $0.94 \mathrm{~g}$ $\mathrm{NaCl}$ ) in Expt 1; whole canned green lentils (183.8 g, NuPak ${ }^{\circledR}$; Shah Trading Company Limited; $70.0 \mathrm{ml}$ filtered water), puréed canned green lentils (183.8 g, NuPak ${ }^{\circledR}$; Shah Trading Company Limited; $70.0 \mathrm{ml}$ filtered water), pre-cooked Eston lentil powder $(47.7 \mathrm{~g}$; manufactured and donated by InfraReady ${ }^{\circledR}$ Products Limited; $204.9 \mathrm{ml}$ filtered water; $1.21 \mathrm{~g}$ $\mathrm{NaCl}$ ) and whole-wheat flour (39.4 g, Robin Hood $^{\circledR}$, Smucker Foods of Canada Company; $213.2 \mathrm{ml}$ filtered water; $1.21 \mathrm{~g}$ $\mathrm{NaCl}$ ) in Expt 2; and whole canned chickpeas (148.8 g, NuPak $^{\circledR}$; Shah Trading Company Limited; $104.7 \mathrm{ml}$ filtered water), puréed chickpeas (148.8g, NuPak ${ }^{\circledR}$; Shah Trading Company Limited; $104.7 \mathrm{ml}$ filtered water), pre-cooked garbanzo bean (chickpea) powder (49.7 g; manufactured and donated by InfraReady ${ }^{\circledR}$ Products Limited; $202.9 \mathrm{ml}$ filtered water; $1.20 \mathrm{~g} \mathrm{NaCl}$ ), or whole-wheat flour (39.4 g, Robin $\operatorname{Hood}^{\circledR}$, Smucker Foods of Canada Company; $213 \cdot 2 \mathrm{ml}$ filtered water; $1.21 \mathrm{~g} \mathrm{NaCl}$ ) in Expt 3.

Commercial navy bean powder was produced by ADM by washing, blanching, cooking, refrying, macerating, drying and grinding navy beans to powder form with a particle size for which $95 \%$ passed through a no. 80 sieve. InfraReady produced the lentil and chickpea powders following a similar processing sequence of washing, tempering, micronisation and flaking, with the exception of short and intense heating in the microniser. Following flaking, flakes were milled in a pinmill to powder form. Overall, $96 \%$ of the lentil powder passed through between no. 40 and 50 sieve sizes, and $85 \%$ of the chickpea powder passed through between no. 30-60 sieves. Additional details were not provided by the manufacturers.

The tomato sauce served with the treatments and control was prepared identically in each study and consisted of the following ingredients: no-salt-added tomato paste (125 g, Hunt's ${ }^{\circledR}$; ConAgra Foods Canada, Inc.); filtered water $(110 \mathrm{ml})$; lemon juice from concentrate $\left(1.2 \mathrm{ml}\right.$, ReaLemon ${ }^{\circledR}$; Cadbury Canada, Inc.); no-salt-added garlic and herb seasoning ( $1.2 \mathrm{ml}$, McCormick ${ }^{\circledR}$; McCormick Canada); dried basil leaves $\left(0.6 \mathrm{ml}\right.$, Equality ${ }^{\circledR}$; The Great Atlantic \& Pacific Company of Canada Limited); ground black pepper $(0.6 \mathrm{ml}$, Equality ${ }^{\circledR}$; The Great Atlantic \& Pacific Company of Canada Limited); garlic powder $\left(1.2 \mathrm{ml}\right.$, Equality ${ }^{\circledR}$; The Great Atlantic \& Pacific Company of Canada Limited); dried parsley flakes $\left(2.5 \mathrm{ml}\right.$, Equality ${ }^{\circledR}$; The Great Atlantic \& Pacific Company of Canada Limited); chilli powder $\left(1.2 \mathrm{ml}\right.$, Selection ${ }^{\circledR}$; Metro Brands); white sugar (1.2 ml; Redpath ${ }^{\circledR}$ Sugar Limited).

The nutritional composition of the pulse treatments and control is listed in Table 1. All treatments and control were of similar available carbohydrate content (38.8g), with $25 \mathrm{~g}$ from the test ingredient (pulses or whole-wheat flour) and $13.8 \mathrm{~g}$ from the tomato sauce. The pulse treatments and control were prepared the day before each session, transferred to airtight containers, combined with water to reach a final weight of $405.0 \mathrm{~g}$, and sealed in airtight containers for overnight storage in an experimental fridge. To prepare the whole-pulse treatments, canned navy beans (Expt 1), lentils (Expt 2) and chickpeas (Expt 3) were poured into a strainer, washed thoroughly under running water for $30 \mathrm{~s}$ and drained well. Pulses were then combined with filtered water while the tomato sauce ingredients were cooked in a non-sticky pan on medium heat $(3 \mathrm{~min})$. The whole pulses were then added 
Table 1. Nutritional composition of the treatments and control

\begin{tabular}{|c|c|c|c|c|c|c|c|c|c|c|}
\hline & & $\begin{array}{c}\text { Energy } \\
(\mathrm{kJ})^{\star}\end{array}$ & $\begin{array}{l}\text { Ash } \\
\text { (g) }\end{array}$ & $\begin{array}{l}\text { Fat } \\
\text { (g) }\end{array}$ & $\begin{array}{l}\text { Protein } \\
\text { (g) }\end{array}$ & $\begin{array}{c}\text { Carbohydrate } \\
\text { (g) }\end{array}$ & $\begin{array}{l}\text { Dietary } \\
\text { fibre }(\mathrm{g})\end{array}$ & $\begin{array}{c}\text { Available } \\
\text { carbohydrate (g) }\end{array}$ & $\begin{array}{c}\mathrm{Na} \\
(\mathrm{mg})\end{array}$ & $\begin{array}{l}\text { Weight } \\
\text { (g) }\end{array}$ \\
\hline \multirow[t]{4}{*}{ Expt 1 (navy beans) } & Whole navy bean & $980 \cdot 1$ & 1.9 & 1.5 & $17 \cdot 5$ & $55 \cdot 0$ & $16 \cdot 3$ & 38.7 & 375.9 & $405 \cdot 0$ \\
\hline & Puréed navy bean & $980 \cdot 1$ & 1.9 & 1.5 & $17 \cdot 5$ & $55 \cdot 0$ & $16 \cdot 3$ & 38.7 & 375.9 & $405 \cdot 0$ \\
\hline & Navy bean powder & $1040 \cdot 4$ & $2 \cdot 1$ & 1.7 & $20 \cdot 5$ & $60 \cdot 1$ & 21.4 & $38 \cdot 7$ & 375.9 & $405 \cdot 0$ \\
\hline & Whole-wheat flour & $817 \cdot 3$ & 0.6 & 0.7 & $9 \cdot 6$ & $46 \cdot 6$ & 7.9 & 38.7 & 375.9 & 405.5 \\
\hline \multirow[t]{4}{*}{ Expt 2 (lentils) } & Whole lentil & $944 \cdot 1$ & 1.8 & 0.9 & $16 \cdot 5$ & $50 \cdot 0$ & $11 \cdot 3$ & $38 \cdot 7$ & $566 \cdot 3$ & 405.5 \\
\hline & Puréed lentil & $944 \cdot 1$ & $1 \cdot 8$ & 0.9 & $16 \cdot 5$ & $50 \cdot 0$ & $11 \cdot 3$ & $38 \cdot 7$ & $566 \cdot 3$ & $405 \cdot 5$ \\
\hline & Lentil powder & $924 \cdot 0$ & $1 \cdot 1$ & 0.8 & $15 \cdot 5$ & $49 \cdot 0$ & $10 \cdot 3$ & $38 \cdot 7$ & $566 \cdot 3$ & 405.5 \\
\hline & Whole-wheat flour & $842 \cdot 0$ & 0.6 & 0.9 & 10.5 & $46 \cdot 6$ & 7.9 & 38.7 & $566 \cdot 3$ & 405.5 \\
\hline \multirow[t]{4}{*}{ Expt 3 (chickpeas) } & Whole chickpea & $1006 \cdot 1$ & 1.6 & 3.6 & $14 \cdot 3$ & $49 \cdot 2$ & 10.5 & 38.7 & $566 \cdot 3$ & 405.5 \\
\hline & Puréed chickpea & $1006 \cdot 1$ & 1.6 & 3.6 & $14 \cdot 3$ & $49 \cdot 2$ & $10 \cdot 5$ & 38.7 & $566 \cdot 3$ & 405.5 \\
\hline & Chickpea powder & $1027 \cdot 0$ & 1.5 & 3.5 & $15 \cdot 6$ & $48 \cdot 3$ & $9 \cdot 6$ & 38.7 & $566 \cdot 3$ & 405.5 \\
\hline & Whole-wheat flour & $842 \cdot 0$ & 0.6 & 0.9 & $10 \cdot 5$ & $46 \cdot 6$ & 7.9 & $38 \cdot 7$ & $566 \cdot 3$ & $405 \cdot 5$ \\
\hline
\end{tabular}

${ }^{*}$ Fibre calculated as $0 \mathrm{~kJ} / \mathrm{g}$.

to the tomato sauce and mixed well, covered and brought to a boil ( $2 \mathrm{~min}$ ). Heat was reduced and the pulse-tomato sauce mixture was simmered for $10 \mathrm{~min}$ and stirred every $2 \mathrm{~min}$. The puréed navy bean, lentil and chickpea treatments were prepared following the same steps as the whole-pulse treatments except that canned pulses were blended in a food processor (KitchenAid Mod: KFP720OB2) for $60 \mathrm{~s}$ immediately before cooking and mixing with the tomato sauce. The pulse powder treatments were similarly produced, beginning with mixing the navy bean (Expt 1), lentil (Expt 2) and chickpea (Expt 3) powders with filtered water and $\mathrm{NaCl}$ while cooking the tomato sauce ingredients in a separate pan. The pulse powder mixture was added to the tomato sauce once it came to a boil, mixed well, covered and brought to a boil again $(2 \mathrm{~min})$. Heat was reduced and the pulse powdertomato sauce mixture was simmered for $10 \mathrm{~min}$ and stirred every $2 \mathrm{~min}$. The whole-wheat flour control was prepared following identical steps as the pulse powder treatments. Before serving, the treatments and control were heated in a microwave oven under high power for $90 \mathrm{~s}$ and served with $250 \mathrm{ml}$ of filtered water.

\section{Protocol}

The present study followed a similar protocol as reported in previous short-term studies from our group ${ }^{(32,33)}$. Following a $10-12 \mathrm{~h}$ overnight fast, participants were instructed to consume a standardised breakfast $(1422.6 \mathrm{~kJ})$ in the morning within $15 \mathrm{~min}$ and arrive at the laboratory $4 \mathrm{~h}$ later. The standardised breakfast was provided to them in advance and consisted of $26 \mathrm{~g}$ of Honey Nut Cheerios cereal (General Mills), $250 \mathrm{ml}$ of Beatrice $2 \%$ milk (Parmalat Canada) and $250 \mathrm{ml}$ of Tropicana orange juice (Tropicana Products, Inc.). In addition, $500 \mathrm{ml}$ of bottled water (Canadian Springs) were included, and participants were required to finish the bottle by $1 \mathrm{~h}$ before the session start time.

Upon arrival, participants were asked to complete a Sleep Habits and Stress Factors Questionnaire and an Activity Questionnaire. If they reported significant deviations from their usual patterns, they were asked to reschedule. Baseline blood samples were obtained by finger prick by a Monojector
Lancet Device (Sherwood Medical), as described previously $^{(12,13)}$, and BG concentrations measured by using a glucose meter (Accu-Chek Compact Plus Glucose Monitor; Roche Diagnostics Canada). The second drop was placed on the testing strip after wiping off the first drop of blood due to contamination with alcohol and interstitial fluid. Each participant was provided with the same glucometer to use throughout the study to reduce intra-subject variation. A baseline BG concentration $>5.5 \mathrm{mmol} / \mathrm{l}$ suggested that the participant had not complied with the protocol, and the session was rescheduled.

After taking baseline measurements for BG, participants were given $15 \mathrm{~min}$ to consume either one of the treatments or control provided to them in random order with $250 \mathrm{ml}$ of filtered water. BG concentration was measured at 15 , 30, 45, 60, 90 and $120 \mathrm{~min}$. At $120 \mathrm{~min}$, participants were asked to consume a fixed-size pizza meal $(50 \cdot 2 \mathrm{~kJ} / \mathrm{kg}$ body weight, McCain Deep 'N Delicious; McCain Foods Limited) with $500 \mathrm{ml}$ of filtered water (which could be consumed ad libitum) within $20 \mathrm{~min}$ in order to measure post-second-meal glycaemic response without the variation introduced by ad libitum food intake. The pizzas averaged $7.6 \mathrm{~g}$ protein, $4.9 \mathrm{~g}$ fat, $29.3 \mathrm{~g}$ carbohydrate and $818.6 \mathrm{~kJ} / 100 \mathrm{~g}$. Each cooked pizza ( $8 \mathrm{~min}$ at $227^{\circ} \mathrm{C}$ and cut in quarters) was weighed before serving. Following the pizza meal, BG concentration was measured repeatedly at 140, 155, 170, 185 and $200 \mathrm{~min}$.

\section{Statistical analyses}

All statistical analyses were performed using SAS version 9.2 (Statistical Analysis Systems; SAS Institute). Effects of time, treatment and treatment $\times$ time interaction on $\mathrm{BG}$ response were analysed using two-way repeated-measures ANOVA. If there was a treatment and/or interaction effect on BG response, one-way repeated-measures ANOVA and TukeyKramer's post hoc test were conducted to determine between-treatment differences at each time point. The effect of treatment on BG AUC was tested via one-way repeated measures ANOVA. All results are presented as means with their standard error of the mean. Differences were considered statistically significant with $P<0 \cdot 05$. 


\section{Results}

\section{Subject characteristics}

A total of seventeen subjects with a mean BMI of 22.9 (SEM 0.3$) \mathrm{kg} / \mathrm{m}^{2}$ and age of 22.1 (SEM 0.8 ) years completed Expt 1. Overall, twelve subjects with a mean BMI of $23 \cdot 2$ (SEM 0.4 ) kg/m $\mathrm{m}^{2}$ and age of 22.2 (SEM 0.9) years completed Expt 2. A total of twelve subjects with a mean BMI of $22 \cdot 3$ (SEM $0 \cdot 4) \mathrm{kg} / \mathrm{m}^{2}$ and age of 23.6 (SEM 1.0) years completed Expt 3.

\section{Blood glucose}

Expt 1 (navy beans). Pre-meal (0-120 min) mean BG concentrations were significantly affected by time $(P<0.0001)$ and time $\times$ treatment interaction $(P<0.0001)$, but no main effect of treatment was detected $(P=0 \cdot 28)$ (Table 2; Fig. 1(A)). Pre-meal BG concentration was lowest at 0 min and increased after treatment consumption. The interactions occurred because the BG response reached peak concentrations at $30 \mathrm{~min}$, but there was a difference in pattern among the treatments over $120 \mathrm{~min}$. At $15 \mathrm{~min}$, BG concentration was lower after the consumption of whole navy beans $(P=0.004)$ and puréed navy beans $(P=0.02)$, but not the powder, compared with the whole-wheat flour control. All the treatments resulted in lower BG concentrations at 30 min compared with the control $(P<0 \cdot 05)$. After the peak, navy bean treatments slowed the decrease in BG concentration compared with the whole-wheat flour control. Navy bean powder led to lower BG concentrations at $45 \mathrm{~min}$ than puréed navy beans $(P=0.03)$; yet at $60 \mathrm{~min}$, the consumption of whole-wheat flour control resulted in lower BG concentrations compared with the consumption of whole navy beans $(P=0.03)$. Main effects of time $(P<0.0001)$ and treatment $(P=0.02)$ were observed following the fixed-energy pizza meal, but there was no time $\times$ treatment interaction $(P=0 \cdot 25)$ (Table 2; Fig. 1(A)). All navy bean treatments and the control increased BG concentrations at 155 min (peak) and gradually decreased BG concentrations until $200 \mathrm{~min}$; however, only whole navy beans suppressed BG concentrations compared with the whole-wheat flour control $(P=0 \cdot 01)$.

Pre-meal BG net AUC was lower for the navy bean powder treatment $(82.9(\mathrm{SEM} 11.4) \mathrm{mmol} \times \mathrm{min} / \mathrm{l})$ than for the wholewheat flour control (116.0 ( $\mathrm{SEM} 12.8) \mathrm{mmol} \times \mathrm{min} / \mathrm{l})(P<0.05)$, but was intermediate for the whole bean $(97 \cdot 2$ (sEm 11.3) $\mathrm{mmol} \times \mathrm{min} / \mathrm{l})$ and puréed (102.1 (sEM 10.8) $\mathrm{mmol} \times$ min/l) treatments. Postprandial BG net AUC was lower for the whole navy bean treatment $(94.5($ SEM 10.1) $\mathrm{mmol} \times \mathrm{min} / \mathrm{l})$ than for the control (123.9 (SEM 15.4) $\mathrm{mmol} \times \mathrm{min} / \mathrm{l})(P<0.05)$; puréed and powdered navy bean treatments led to intermediate responses $(102.0(\mathrm{SEM} 10 \cdot 4) \mathrm{mmol} \times \mathrm{min} / \mathrm{l}$ and 114.5 (SEM 11.5$) \mathrm{mmol} \times \mathrm{min} / \mathrm{l}$, respectively).

Expt 2 (lentils). Pre-meal mean BG concentration was significantly affected by time $(P<0.0001)$, treatment $(P=0.0001)$ and time $\times$ treatment interaction $(P=0.0008)$ (Table 2; Fig. 1(B)). Pre-meal BG response was lowest at 0 min and increased after treatment consumption. During the pre-meal period (0-120 min), mean BG concentrations were lower for all lentil treatments than for the whole-wheat flour control $(P<0.05)$. The interaction is explained by the variation in the effect of the treatment at specific time points. At 15 and $30 \mathrm{~min}$, the whole and purée lentil treatments led to a lower BG response compared with the whole-wheat flour treatment $(P<0.05)$, while the lentil powder led to an intermediate response. Postprandial BG concentration (120-200 min) was affected by time $(P<0 \cdot 0001)$, but there was no main effect of treatment $(P=0.65)$ or time $\times$ treatment interaction $(P=0.43)$ (Table 2; Fig. 1(B)). All lentil treatments and the control

Table 2. Absolute pre- and post-meal blood glucose concentrations (Mean values with their standard errors)

\begin{tabular}{|c|c|c|c|c|c|}
\hline & \multirow[b]{2}{*}{ Treatment } & \multicolumn{2}{|c|}{ Pre-meal $(\mathrm{mmol} / \mathrm{l})^{\star}$} & \multicolumn{2}{|c|}{ Post-meal $(\mathrm{mmol} / \mathrm{l}) \dagger$} \\
\hline & & Mean & $\overline{\text { SEM }}$ & Mean & SEM \\
\hline \multirow[t]{4}{*}{ Expt 1 (navy beans; $n 17$ ) } & Whole navy bean & $5 \cdot 57$ & $0 \cdot 10$ & $5 \cdot 78^{a}$ & $0 \cdot 10$ \\
\hline & Puréed navy bean & 5.63 & $0 \cdot 10$ & $5 \cdot 95^{\mathrm{a}, \mathrm{b}}$ & $0 \cdot 10$ \\
\hline & Navy bean powder & 5.59 & $0 \cdot 10$ & $6 \cdot 05^{a, b}$ & 0.11 \\
\hline & $\begin{array}{l}\text { Whole-wheat flour } \\
P\end{array}$ & 0.29 & 0.12 & $6 \cdot 12^{\mathrm{b}}$ & 0.12 \\
\hline \multirow[t]{5}{*}{ Expt 2 (lentils; $n$ 12) } & Whole lentil & $5 \cdot 54^{\mathrm{a}}$ & $0 \cdot 10$ & 6.09 & 0.12 \\
\hline & Puréed lentil & $5 \cdot 64^{a}$ & 0.11 & 6.04 & 0.12 \\
\hline & Lentil powder & $5 \cdot 65^{\mathrm{a}}$ & $0 \cdot 12$ & 6.09 & 0.13 \\
\hline & Whole-wheat flour & \multirow{2}{*}{\multicolumn{2}{|c|}{0.0001}} & $6 \cdot 19$ & 0.14 \\
\hline & $P$ & & & \multicolumn{2}{|c|}{0.65} \\
\hline \multirow{5}{*}{ Expt 3 (chickpeas; $n$ 12) } & Whole chickpea & $5 \cdot 83^{a}$ & $0 \cdot 11$ & $6 \cdot 11$ & 0.12 \\
\hline & Puréed chickpea & $5 \cdot 71^{a}$ & 0.12 & 6.08 & 0.14 \\
\hline & Chickpea powder & $5 \cdot 80^{\mathrm{a}}$ & $0 \cdot 12$ & 6.07 & 0.11 \\
\hline & Whole-wheat flour & \multirow{2}{*}{\multicolumn{2}{|c|}{$\begin{array}{ll}6.04^{b} & 0.14 \\
0.002 & \end{array}$}} & $6 \cdot 18$ & 0.12 \\
\hline & $P$ & & & \multicolumn{2}{|c|}{0.67} \\
\hline
\end{tabular}

${ }^{\mathrm{a}, \mathrm{b}}$ Mean values within a column with unlike superscript letters were significantly different from each other $(P<0.05$; two-way ANOVA, Tukey-Kramer post hoc test).

${ }^{*}$ Pre-meal values are means of all observations before the pizza meal: 0, 15, 30, 45, 60, 90 and $120 \mathrm{~min}$.

$\dagger$ Post-meal values are means of all observations after the pizza meal: 120, 140, 155, 170, 185 and $200 \mathrm{~min}$. 

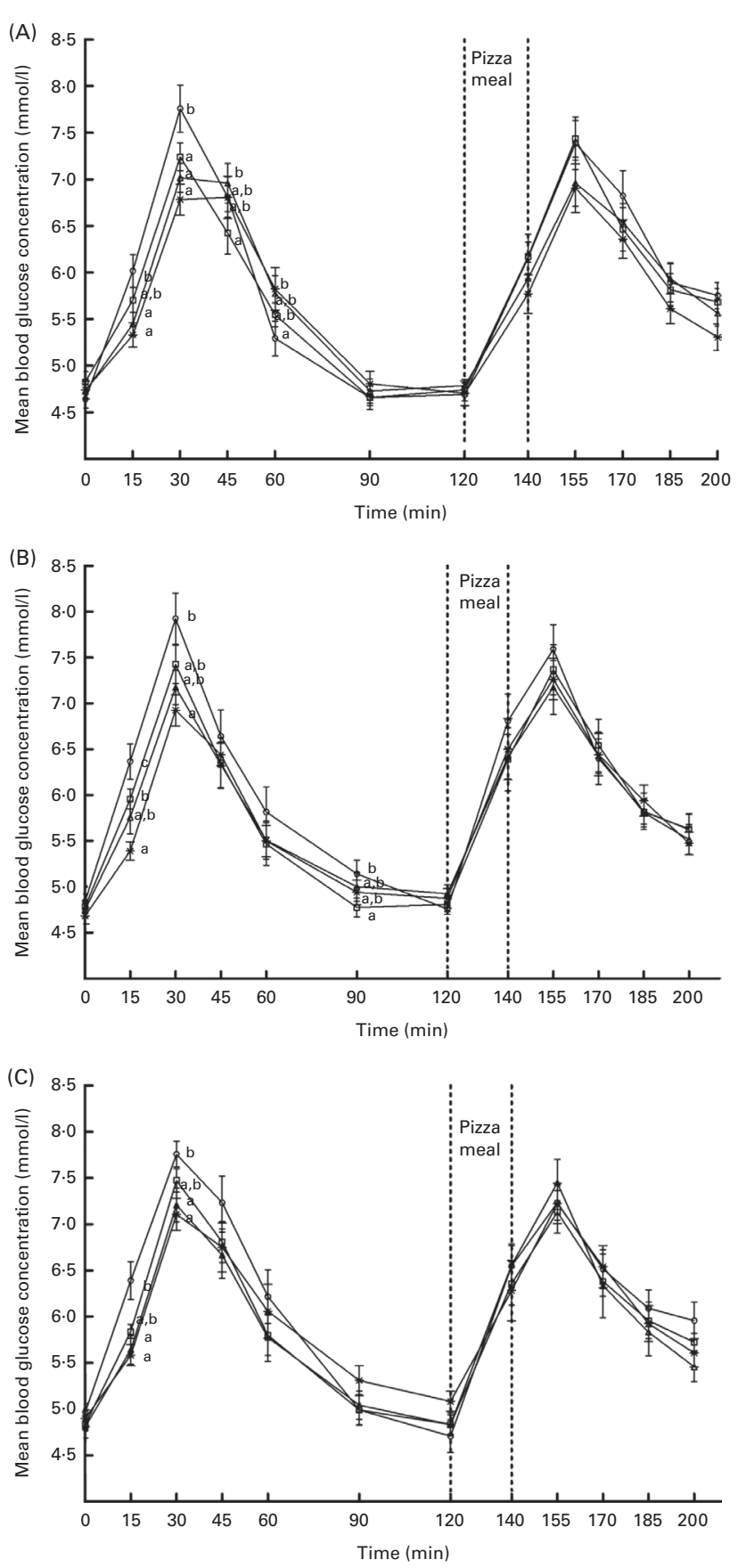

Fig. 1. Effect of the treatments on absolute blood glucose concentration over time. (A) Expt 1, (B) Expt 2 and (C) Expt 3. Values are means ( $n 17$ in Expt 1, $n 12$ in Expt 2 and $n 12$ in Expt 3), with their standard errors represented by vertical bars. ${ }^{a, b}$ Mean values with unlike letters were significantly different at each measured time point $(P<0.05$; one-way ANOVA, TukeyKramer post hoc test). (A) $*$, Whole navy bean; $\triangle$, puréed navy bean; $\square$, navy bean powder; $\odot$, whole-wheat flour. (B) $*$, Whole lentil; $\triangle$, puréed lentil; $\square$, lentil powder; $\bullet$, whole-wheat flour. (C) $\rightarrow$, Whole chickpea; $\triangle$, puréed chickpea; $\square$, chickpea powder; $\bullet$, whole-wheat flour.

increased BG concentrations similarly at $155 \mathrm{~min}$ (peak) and gradually decreased BG concentrations until $200 \mathrm{~min}$.

Whole lentils $(97 \cdot 1(\operatorname{sem} 10 \cdot 1) \mathrm{mmol} \times \mathrm{min} / \mathrm{l})$ and lentil powder (95.8 (SEM 9.6) $\mathrm{mmol} \times \mathrm{min} / \mathrm{l})$ led to lower pre-meal BG net AUC compared with the whole-wheat flour control
(125.8 (sem 15.0) $\mathrm{mmol} \times \mathrm{min} / \mathrm{l})(P<0 \cdot 05)$; puréed lentils led to an intermediate response (102.4 (SEM 8.4) $\mathrm{mmol} \times \mathrm{min} / \mathrm{l})$. Postprandial BG AUC was not affected by treatment (108.3 (SEM 16.0), 94.2 (SEM 10.4), 113.4 (SEM 17.1) and $125 \cdot 5$ (SEM 16.4) $\mathrm{mmol} \times \mathrm{min} / 1$ for whole lentils, puréed lentils, lentil powder and control, respectively).

Expt 3 (chickpeas). Pre-meal mean BG concentration was significantly affected by time $(P<0 \cdot 0001)$, treatment $(P=0.002)$ and time $\times$ treatment interaction $(P<0.0001)$ (Table 2; Fig. 1(C)). Pre-meal BG response was lowest at 0 min and increased after treatment consumption. During the pre-meal period (0-120 min), BG concentration was lower following the consumption of whole, puréed and powdered chickpeas compared with the whole-wheat flour control $(P<0.05)$. $\mathrm{BG}$ response at 15 and $30 \mathrm{~min}$ was lower for the whole and puréed chickpea treatments than for the control; chickpea powder led to a marginally lower response $(P=0.057)$. Following the pizza meal (120-200 min), a main effect was observed for time $(P<0.0001)$ but not for treatment $(P=0.67)$ or time $\times$ treatment interaction $(P=0.36)$ (Table 2 ; Fig. 1(C)). BG concentration peaked comparably for all the treatments and control at $155 \mathrm{~min}$ and gradually decreased until $200 \mathrm{~min}$.

BG net AUC was not affected by treatment either pre- or postmeal. The net AUC values before and after the pizza meal for the whole, puréed and powdered chickpea treatments were as follows: 112.2 (SEM 11.4) and $91.6(\mathrm{sem} \mathrm{14.8)} \mathrm{mmol} \times \mathrm{min} / \mathrm{l}$; $105.5(\mathrm{SEM} 8.0)$ and $111.6(\mathrm{SEM} 19.9) \mathrm{mmol} \times \mathrm{min} / \mathrm{l} ; 110 \cdot 9$ (SEM 10.5) and $108.0($ SEM 12.3$) \mathrm{mmol} \times \mathrm{min} / \mathrm{l}$. The pre- and post-meal values for the whole-wheat flour control were $122 \cdot 3$ $(\operatorname{sem} 12 \cdot 7) \mathrm{mmol} \times \mathrm{min} / \mathrm{l}$ and $127 \cdot 4(\operatorname{sem} 13 \cdot 0) \mathrm{mmol} \times \mathrm{min} / 1$, respectively.

\section{Discussion}

Overall, no differences in BG response were observed between the pulse treatments due to processing between whole canned pulses, puréed canned pulses and pulse powders, indicating that puréeing and industrial processing of pulses to powder forms does not eliminate their benefits on short-term glucose regulation ${ }^{(11-13)}$.

Similar to the puréed canned lentils and chickpea treatments, pre-cooked lentil and chickpea powders prepared by a similar process suppressed BG response over $120 \mathrm{~min}$. In contrast, powdered navy beans, along with whole and puréed navy beans, had a less pronounced effect as evidenced by suppressing BG peak concentrations only at $30 \mathrm{~min}$ compared with whole-wheat flour control and leading to a more attenuated decline after peaking. The overall lower (4-6\%) mean pre-meal glycaemic response to the control in Expt 1 compared with Expt 2 and 3 may have also contributed to the findings that the navy bean treatments did not result in a lower overall BG response compared with the control, while the lentil and chickpea treatments did. Possible reasons for this inconsistency in the response to the control between the experiments include differences in the batches of wholewheat flour used to prepare the control, small differences in the composition of the controls, and inter-subject variability. 
The results of the present study contrast with a previous report indicating that lentil powder prepared in a laboratory setting by boiling lentils for $20 \mathrm{~min}$, puréeing, drying for $12 \mathrm{~h}$ at $121^{\circ} \mathrm{C}$ and then grinding to a powder produced a significantly greater glycaemic response compared with boiled whole lentils ${ }^{(23)}$. This discrepancy could be due to the differences in processing. Cooking time of pulses positively correlates with starch hydrolysis rate ${ }^{(34)}$. It is possible that drying for $12 \mathrm{~h}$ at $121^{\circ} \mathrm{C}$ leads to increased starch gelatinisation, thus making starch granules more readily available for digestion ${ }^{(35)}$. In addition, protein is located between starch granules in the cells; protein denaturation and digestion by enzymes and acids leads to increased accessibility of $\alpha$-amylase to the starch, resulting in higher digestibility in pulses ${ }^{(22)}$. Heating also causes protein denaturation ${ }^{(35)}$, which may have led to increased accessibility of enzymes to starch granules resulting in higher digestibility.

Processing times in industrial preparations are much shorter than those in home or laboratory settings, as they are optimised to soften and achieve the best textural characteristics of pulses. For example, the micronisation technique used to produce lentil and chickpea powders is a process widely used in the production of cooked, flaked cereals and instant pulse products ${ }^{(36)}$. In this process, grains are exposed to electromagnetic radiation in the wavelength region of $1 \cdot 8-3.4 \mu \mathrm{m}^{(37)}$ for $2-3 \mathrm{~min}^{(38)}$. These IR waves cause molecules to vibrate at $60000-150000 \mathrm{MHz}$, thereby producing a rapid internal heat. The temperature can reach approximately $140^{\circ} \mathrm{C}$ and all starches are gelatinised within $2-3 \min ^{(37,38)}$. The grains are then flaked and milled into powders ${ }^{(37)}$. In contrast, the navy bean powder used in Expt 1 was processed differently compared with the lentil and chickpea powders. The navy bean powder was produced by the conventional method of blanching, cooking, refrying, macerating, drying, and size reduction; nevertheless, the product produced had similar effects to the whole bean.

In the present study, cooking first and then grinding to produce pulse powders did not change the low glycaemic property of the cooked pulses. Cooking whole pulses and then grinding to produce pulse powders disrupts the cotyledon structure yet preserves the integrity of the cell walls that encapsulate the starch granules ${ }^{(39,40)}$. When pulse powders are prepared by grinding pulses before cooking, the cell walls break down ${ }^{(22)}$ and release $\operatorname{starch}^{(22,25)}$. Thus, these powders contain mostly free starches ${ }^{(22)}$. Previously, it has been shown that pulse powders obtained by grinding raw pulses and then cooking result in a higher peak BG response than after consumption of cooked whole pulses ${ }^{(25)}$ and powders made from cooked whole pulses ${ }^{(24)}$.

The role of particle size in the pre-meal glycaemic response was not elucidated by the present study. Despite differences in particle size (navy bean $180 \mu \mathrm{m}$ or less, chickpea 300-425 $\mu \mathrm{m}$ and lentil 250-600 $\mu \mathrm{m}$ ) between the pulse powders, they led to similar BG responses to those for the whole and puréed pulse treatments. Particle size would have been greatest for the chewed whole pulses, and, thus, if it played a major role, BG would have been significantly lower after consumption of the whole pulses.
A lower BG response following the pizza meal was observed only after the consumption of whole navy beans, which suggests that smaller particle size may have accounted for the reduced effect of puréed and powdered navy beans after a second meal. Seed tissue architecture plays an important role in maintaining prolonged glucose absorption of intact pulses ${ }^{(24)}$. If particle size was a contributing factor, the larger particle size of the navy been powder should have resulted in a similar postprandial decrease to that of the whole beans following the pizza meal. Furthermore, postprandial BG responses for the lentil and chickpea powders, which were smaller in particle size, should have led to higher responses compared with the whole-pulse treatments. However, lentil and chickpea powders did not differ from either the whole and puréed treatments or the control in Expt 2 and 3, respectively. This observation warrants additional studies to examine the differences between pulse varieties and processing within the same experiments.

The strengths of the present study include that the treatments contained the same amount of available carbohydrate, had amounts of powders reflective of those that would be used as value-added ingredients, and featured powders currently available on the market. However, differences in processing, protein and dietary fibre contents, and particle size of the treatments may be confounders of the outcomes. Also, the experiments may have been underpowered to detect the differences in BG responses between the pulse treatments at specific time points. Finally, the study was a comparison of commercially produced canned pulses with powdered pulses. Previous studies have shown that canning pulses can lead to higher glycaemic responses ${ }^{(24,34,41)}$, while others have shown no difference ${ }^{(11)}$. Thus, to compare with previous studies ${ }^{(23,24)}$, it would have been informative to have included dried whole pulses cooked as they would be in the home to compare with the whole canned pulses. Finally, the present study was conducted in young normalweight males, and, thus, further research into the effects of pea fractions on BG regulation in other populations, including females and overweight/obese adults, is necessary.

In conclusion, commercial processing of pulses to a powder form does not alter their low glycaemic characteristics. Pulse powders can therefore be used as value-added ingredients in home cooking and functional foods to improve postprandial glycaemic control. It is expected that the development of such foods will help promote consumption of pulses in convenience foods among individuals who normally avoid them due to taste or perceived inconvenience.

\section{Acknowledgements}

The authors acknowledge the participants who volunteered to participate in the study.

The present study was supported by Agriculture and Agri-Food Canada (AAFC) under the Pulse Science Cluster initiative.

The authors' contribution are as follows: G. H. A., B. L. L., C. E. S. and Y. L. designed the study; Y. L. and T. T. L. conducted the experiments; Y. L., C. E. S., M. F. N., R. C. M. 
and G. H. A. contributed to the writing and reviewing of the manuscript; Y. L. conducted the primary analysis of the data; G. H. A. had primary responsibility for the final content of the manuscript.

The authors declare that there are no conflicts of interest.

\section{References}

1. World Health Organization (2013) Obesity and overweight: Fact sheet no. 311. http://www.who.int/mediacentre/fact sheets/fs311/en/

2. Kahn SE, Hull RL \& Utzschneider KM (2006) Mechanisms linking obesity to insulin resistance and type 2 diabetes. Nature 444, 840-846.

3. Pulse Canada (2012) Canada's pulse industry in the global market. http://www.pulsecanada.com/statistics

4. Mitchell DC, Lawrence FR, Hartman TJ, et al. (2009) Consumption of dry beans, peas, and lentils could improve diet quality in the US population. J Am Diet Assoc 109, 909-913.

5. Mudryj AN, Yu N, Hartman TJ, et al. (2012) Pulse consumption in Canadian adults influences nutrient intakes. Br J Nutr 108, Suppl. 1, S27-S36.

6. Papanikolaou Y \& Fulgoni VL 3rd (2008) Bean consumption is associated with greater nutrient intake, reduced systolic blood pressure, lower body weight, and a smaller waist circumference in adults: results from the National Health and Nutrition Examination Survey 1999-2002. J Am Coll Nutr 27, 569-576.

7. Sievenpiper JL, Kendall CW, Esfahani A, et al. (2009) Effect of non-oil-seed pulses on glycaemic control: a systematic review and meta-analysis of randomised controlled experimental trials in people with and without diabetes. Diabetologia 52, 1479-1495.

8. Jenkins DJ, Wolever TM, Taylor RH, et al. (1980) Exceptionally low blood glucose response to dried beans: comparison with other carbohydrate foods. Br Med J 281, 578-580.

9. Jenkins DJ, Wolever TM, Taylor RH, et al. (1981) Glycemic index of foods: a physiological basis for carbohydrate exchange. Am J Clin Nutr 34, 362-366.

10. Foster-Powell K, Holt SH \& Brand-Miller JC (2002) International table of glycemic index and glycemic load values: 2002. Am J Clin Nutr 76, 5-56.

11. Wong CL, Mollard RC, Zafar TA, et al. (2009) Food intake and satiety following a serving of pulses in young men: effect of processing, recipe, and pulse variety. J Am Coll Nutr 28, 543-552.

12. Mollard RC, Wong CL, Luhovyy BL, et al. (2011) First and second meal effects of pulses on blood glucose, appetite, and food intake at a later meal. Appl Physiol Nutr Metab 36, 634-642.

13. Mollard RC, Zykus A, Luhovyy BL, et al. (2011) The acute effects of a pulse-containing meal on glycaemic responses and measures of satiety and satiation within and at a later meal. Br J Nutr 108, 508-517.

14. Pai S, Ghugre PS \& Udipi SA (2005) Satiety from rice-based, wheat-based and rice-pulse combination preparations. Appetite 44, 263-271.

15. Sparti A, Milon H, Di Vetta V, et al. (2000) Effect of diets high or low in unavailable and slowly digestible carbohydrates on the pattern of 24-h substrate oxidation and feelings of hunger in humans. Am J Clin Nutr $\mathbf{7 2}$, $1461-1468$.
16. Leathwood P \& Pollet P (1988) Effects of slow release carbohydrates in the form of bean flakes on the evolution of hunger and satiety in man. Appetite 10, 1-11.

17. Holt SHA (1995) A satiety index of common foods. Eur J Clin Nutr 49, 675.

18. Ceriello A, Colagiuri S, Gerich J, et al. (2008) Guideline for management of postmeal glucose. Nutr Metab Cardiovasc Dis 18, $\mathrm{S} 17-\mathrm{S} 33$.

19. Association AD (2001) Postprandial blood glucose. American Diabetes Association. Diabetes Care 24, 775-778.

20. Ryland D, Vaisey-Genser M, Arntfield SD, et al. (2010) Development of a nutritious acceptable snack bar using micronized flaked lentils. Food Res Int 43, 642-649.

21. Han J, Janza JAM \& Gerlatb M (2010) Development of gluten-free cracker snacks using pulse flours and fractions. Food Res Int 43, 627-633.

22. Wursch P, Del Vedovo S \& Koellreutter B (1986) Cell structure and starch nature as key determinants of the digestion rate of starch in legume. Am J Clin Nutr 43, 25-29.

23. Jenkins DJ, Thorne MJ, Camelon K, et al. (1982) Effect of processing on digestibility and the blood glucose response: a study of lentils. Am J Clin Nutr 36, 1093-1101.

24. Tovar J, Granfeldt Y \& Bjorck I (1992) Effect of processing on blood glucose and insulin response to starch in legumes. J Agr Food Chem 40, 1846-1851.

25. O'Dea K \& Wong S (1983) The rate of starch hydrolysis in vitro does not predict the metabolic responses to legumes in vivo. Am J Clin Nutr 38, 382-387.

26. Bellido G, Arntfield SD, Cenkowski S, et al. (2006) Effects of micronization pretreatments on the physicochemical properties of navy and black beans (Phaseolus vulgaris L.). LWT Food Sci Technol 39, 779-787.

27. US Dry Pea \& Lentil Council (2013) Processing methods for dry peas, lentils \& chickpeas. http://www.pea-lentil.com/ core/files/pealentil/uploads/files/Chapter4.pdf

28. World Health Organization (2012) Obesity and overweight. http://www.who.int/mediacentre/factsheets/fs311/en/

29. Wolever TM \& Bolognesi C (1996) Prediction of glucose and insulin responses of normal subjects after consuming mixed meals varying in energy, protein, fat, carbohydrate and glycemic index. J Nutr 126, 2807-2812.

30. Brouns F, Bjorck I, Frayn KN, et al. (2005) Glycaemic index methodology. Nutr Res Rev 18, 145-171.

31. Mollard RC, Wong CL, Luhovyy BL, et al. (2014) Second-meal effects of pulses on blood glucose and subjective appetite following a standardized meal $2 \mathrm{~h}$ later. Appl Physiol Nutr Metab 39, 849-851.

32. Anderson GH, Tecimer SN, Shah D, et al. (2004) Protein source, quantity, and time of consumption determine the effect of proteins on short-term food intake in young men. J Nutr 134, 3011-3015.

33. Anderson GH, Catherine NL, Woodend DM, et al. (2002) Inverse association between the effect of carbohydrates on blood glucose and subsequent short-term food intake in young men. Am J Clin Nutr 76, 1023-1030.

34. Traianedes K \& O'Dea K (1986) Commercial canning increases the digestibility of beans in vitro and postprandial metabolic responses to them in vivo. Am J Clin Nutr $\mathbf{4 4}$, 390-397.

35. Newsome R (1986) Effects of food processing on nutritive values. Food Technol 40, 109-116.

36. Cenkowski S \& Sosulski FW (1998) Cooking characteristics of split peas treated with infrared heat. Trans ASAE $\mathbf{4 1}$, $715-720$. 
37. Collier G, McLean A \& O'Dea K (1984) Effect of co-ingestion of fat on the metabolic responses to slowly and rapidly absorbed carbohydrates. Diabetologia 26, 50-54.

38. Arntfield SD, Scanlon MG, Malcolmson LJ, et al. (1997) Effect of tempering and end moisture content on the quality of micronized lentils. Food Res Int 30, 371-380.

39. Tovar J, Bjorck I \& Asp NG (1990) Analytical and nutritional implications of limited enzymic availability of starch in cooked red kidney beans. J Agr Food Chem 38, 488-493.

40. Tovar J, Bjorck I \& Asp NG (1990) Starch content and $\alpha$-amylolysis rate in precooked legume flours. J Agr Food Chem 38, 1818-1823.

41. Wolever TM, Jenkins DJ, Thompson LU, et al. (1987) Effect of canning on the blood glucose response to beans in patients with type 2 diabetes. Hum Nutr Clin Nutr 41, 135-140. 